\title{
Chemical transformations in treatment of saline solution with ozone-oxygen gas mixture
}

\author{
Gennady Andreevich Boyarinov', Alexander Sergeevich Gordetsov², Sergey Petrovich Peretyagin ${ }^{3}$, \\ Larisa Velentinovna Boyarinova², Andrey Kimovich Martusevich ${ }^{4}$ \\ 'Higher Vocational State School in Kalisz, Poland \\ ${ }^{2}$ SFEI HPE Nizhny Novgorod State Medical Academy, Ministry of Public Health, Nizhny Novgorod, Russia \\ ${ }^{3}$ FSFEI Volga Federal Medical Research Centre, Ministry of Public Health, Nizhny Novgorod, Russia \\ ${ }^{4}$ Federal State Institution of Nizhny Novgorod, Research Institute of Traumatology and Orthopaedics, Nizhniy Novgorod, Russia
}

\begin{abstract}
This paper contains the analysis of published reference data related to the ozone and $\mathrm{NaCl}$ interaction in aqueous solutions with different content of $\mathrm{NaCl}(0.9 \%, 1 \%, 3 \%, 5 \%$, and $10 \%)$ therein and their bubbling by the ozone-oxygen gas mixture with the ozone concentration ranging from 10 to $100 \mathrm{mg} / \mathrm{l}$ within 10 to 120 minutes. The authors of the papers under study by using the protonography, chemical, spectrophotometric, and cristalloscopic research methods identified in ozonated solutions potentially possible products of the ozone and sodium chloride reaction in water: hexagonal aqueous structure, sodium hypochlorite, hypochloric acid, chlorates $\left(\mathrm{ClO}^{-}, \mathrm{ClO}_{2}^{-}, \mathrm{ClO}_{3}^{-}\right)$, nitrite, nitrate $\left(\mathrm{NO}_{2}^{-}\right.$and $\left.\mathrm{NO}_{3}^{-}\right)$, free radicals, hydrogen peroxide, as well as dissolved ozone and oxygen. From the performed analysis of published reference data it follows, that when treating these solutions with the ozone-oxygen gas mixture and in the subsequent disintegration of ozone therein, the latter interacts neither with $\mathrm{Na}^{+}$nor with $\mathrm{Cl}^{-}$; sodium hypochlorite and other chlorine-containing oxygen ions, nitrates, and nitrites are not formed herewith. There are identified dissolved oxygen and ozone, and in the interaction of the latter with water free radicals, hydrogen peroxide, hexagonal, and low-molecular aqueous structures are generated.
\end{abstract}

KEY WORDS: products of the ozone, $\mathrm{NaCl}$ interaction, in aqueous solutions.

ADDRESS FOR CORRESPONDENCE: Prof. Gennady Andreevich Boyarinov, State Higher School of Vocational Education,

Kalisz, Poland, e-mail: boyarin46@mail.ru

\section{INTRODUCTION}

The method of the ozone-saturated saline solution infusion $(\mathrm{NaCl} 0.9 \%)$ is the priority of the Soviet School of ozone therapists and it is widely used in the treatment of many diseases both in Russia and near abroad. The pronounced therapeutic effect of this ozone treatment procedure is mainly associated with the formation of ozonides in the interaction of dissolved ozone with biological substrates in the patient's organism [1-3]. The successful promotion of ozone in the medical practice makes professionals more thoroughly study any available information on its physical and chemical properties, and try to deepen and expand thereof. By using aqueous ozone-saturated solutions, we should better know and understand the specific gas behavior in these media, peculiarities of reactions, and the nature of intermediate species. The latter often display their biochemical activity and may be used in a disease treatment $[4,5]$. Any issues relating to the dissolution and disintegration of ozone in the saline solution, and the processes of the hypothetical ozone and sodium chloride reactions draw the attention of professionals, who uses the ozonated saline solution for medical purposes, and being often nearly non-justified scientifically as the subject for discussion. So, in researches of Boyarinov and Zaitsev [6, 7], it was established that in treatment of saline solution with ozone, no chlorine - oxygen compounds are formed. 
At the same time, thermodynamic calculations show that in the acidic and alkaline medium, the formation of hypochlorite-anion from anion chloride is possible under exposure to ozone. For example, according to the data provided by Zaitsev [7] (Table 1), the oxidation potential of the $\mathrm{O}_{3} \mathrm{ClO}^{-}$pair is equal to $0.58 \mathrm{~V}$ for the acid medium, and $0.35 \mathrm{~V}$ for the alkaline medium. In the both cases, $\mathrm{E}>0$ and $\Delta \mathrm{G}<0$, thus it confirms the possibility of the reaction under discussion:

$$
\mathrm{O}_{3}+\mathrm{Cl}^{-} \rightarrow \mathrm{O}_{2}+\mathrm{ClO}^{-}
$$

There is no thermodynamic data published on the oxidation potentials of the pairs under discussion in the neutral medium. Therefore, it is not yet possible to provide the correct reasoning. Undoubtedly, appropriate experiments are to be conducted at different $\mathrm{pH}$ and concentrations of the solution. But this is only of theoretical interest, since for medical purposes a neutral saline solution is used with its concentration of $0.9 \%$. As it follows from published sources, when using ozonated solutions, no hypochlorite-anion is formed therein.

At the same time, it is known that ozone is a strong oxidant. It oxidizes all metals, except for gold and metals of the platinum group, and it reacts with the majority of other elements, decomposes halogen hydrides (except for HF), transforms lower oxides to higher oxides, reacts nearly with all types of hydrocarbons and any other organic compounds [5]. In this regard, some authors [8-10] do not exclude the possibility for the formation of ozonides of alkali metals, type $\mathrm{MO}_{3}$, sodium hypochlorite, hypochlorous acid, and chlorates $\mathrm{ClO}^{-}, \mathrm{ClO}_{2}^{-}$, $\mathrm{ClO}_{3}^{-}$, nitrites, nitrates $\left(\mathrm{NO}_{2}^{-}\right.$and $\left.\mathrm{NO}_{3}^{-}\right)$, and hydrogen peroxide in the treatment of saline solution with ozone. It should be herewith noted that the formation of all these products, except for $\mathrm{H}_{2} \mathrm{O}_{2}$, is thermodynamically unlikely under normal conditions. Nevertheless, single research teams have conducted the studies of potentially possible (in their opinion) ozone reaction with sodium chloride in water.

Zaitsev [7] treated the $1 \%$ and $3 \%$ aqueous solution of sodium chloride with ozone in a special reactor, where the ozone-oxygen gas mixture with the ozone concentration of $60 \mathrm{mg} / \mathrm{l}$ and at the gas flow rate of $11 / \mathrm{min}$ was bubbled through the solution within 10 to 20 minutes. In such treated solutions, hypochlorite was determined by a standard iodometric method. As a result of experiments carried out no hypochlorite was revealed in the treated sodium chloride solutions. Based on these studies, the authors draw the conclusion that with the dissolution of ozone used for medical purposes in the saline solution no hypochlorite is formed.

Boyarinov [6] ozonated the saline solution $(\mathrm{NaCl}$, $0.9 \%$ ) for 60 and 120 minutes in standard $200 \mathrm{ml}$ vials at an ambient temperature of $17-20^{\circ} \mathrm{C}$ by the method of bubbling the ozone-oxygen gas mixture obtained in ozonizer Ozone-M-100 through an air needle. The studied ozone concentrations at the device output were: $10,25,35$, and $100 \mathrm{mg} / \mathrm{l}$. Ozonized solutions and saline (control) solution were analyzed by using Perkin-Elmer Spectrophotometer Coleman 575 (UV spectra) and Specord IR M-80 (IR spectra). Previously, by the same devices, the UV and IR spectra of fresh-prepared standard solutions of sodium hypochlorite $(\mathrm{NaOCl})$ were measured. In the UV spectrum, herewith the intense absorption band was identified with its maximum at $292 \mathrm{~nm}$ - ion $\mathrm{OCl}^{-}$. In the UV spectrum of the ozonized saline solution, there was an oxygen absorption band identified (200-203 nm) and a broad ozone absorption band with its maximum at $\lambda=255 \mathrm{~nm}$ (the Hartley band). It follows from the analysis of this curve and the comparison to the standard that the UV-spectra in samples of ozonized $\mathrm{NaCl}$ solutions of the $\mathrm{OCl}^{-}$group contain no absorption bands, and the character of the curve herewith shows that sodium hypochlorite is not formed in the saline solution ozonation even as impurities. In the IR spectrum, the $\mathrm{OCl}^{-}$band is not characteristic and it is not found in a reference sample. The study of the IR spectra in aqueous solutions of ozonized sodium chloride, and the IR spectra of their concentrates or dry residues showed that they did not contain even trace amounts of any other chlorine-oxygen-containing ions, which generally had the intense absorption bands with their maxima at $790 \mathrm{~cm}^{-1}\left(\mathrm{ClO}_{2}^{-}\right), 980-930 \mathrm{~cm}^{-1}$ $\left(\mathrm{ClO}_{3}^{-}\right), 1140-1060 \mathrm{~cm}^{-1}\left(\mathrm{ClO}_{4}^{-}\right)$. Based on the analysis of the obtained results, the authors make the conclusion that even a long-term bubbling (for up to 120 minutes) of the saline solution $(0.9 \%)$ by ozone of different concentrations (up to $100 \mathrm{mg} / \mathrm{l}$ ) is not accompanied by the formation of chlorine-oxygen-containing ions, and it enables to recommend the using of the saline solution as the infusion medium to be administered parenterally to a patient as an ozone carrier.

Kudryavtsev and Bolshuhin [11] investigated the ozone concentration in solutions simultaneously by two methods. The ozone concentration was assessed spectrophotometrically through the absorption in the region of the Hartley band (the length of $254.5 \mathrm{~nm}$ ), and the total oxidative activity was evaluated by the iodometric titration. The solution ozonation was performed by bubbling with the ozone-oxygen mixture through a ceramic splitter. It was found that the total oxidation activity of dis-

TABLE 1. Oxidation potentials of the ozone-oxygen, and hypochlorite-chloride pair in the alkali and acid medium

\begin{tabular}{|l|c|}
\hline Electrode process & $\mathrm{E}^{0}, \mathrm{~B}$ \\
\hline $\mathrm{O}_{3}+\mathrm{H}_{2} \mathrm{O}+3 \mathrm{e}^{-}=\mathrm{O}_{2}+2 \mathrm{OH}^{-}$ & 1.24 \\
\hline $\mathrm{O}_{3}+2 \mathrm{H}^{+}+2 \mathrm{e}^{-}=\mathrm{O}_{2}+\mathrm{H}_{2} \mathrm{O}$ & 2.07 \\
\hline $\mathrm{ClO}^{-}+\mathrm{H}_{2} \mathrm{O}+2 \mathrm{e}^{-}=\mathrm{Cl}^{-}+2 \mathrm{OH}^{-}$ & 0.88 \\
\hline $\mathrm{HClO}+\mathrm{H}^{+}+2 \mathrm{e}^{-}=\mathrm{Cl}^{-}+\mathrm{H}_{2} \mathrm{O}$ & 1.494 \\
\hline
\end{tabular}


tilled water, saline $(0.9 \%)$ and hypertensive (10\%) solution after their 20-minute bubbling by the ozone-oxygen mixture with the ozone concentration of $10 \mathrm{mg} / \mathrm{l}$ were slightly different and amounted respectively: 3.0, 3.07, and $3.14 \mathrm{mg} / \mathrm{l}$, while the ozone concentration for those solutions was essentially different: $2.55,1.71$, and 0.89 $\mathrm{mg} / \mathrm{l}$. When comparing these data, the authors assumed that the formation in ozonized solutions of secondary oxidants, type $\mathrm{H}_{2} \mathrm{O}_{2}, \mathrm{OH}^{\star}, \mathrm{OH}^{-}$, and possibly of any other reactive oxygen species resulting from the ozone and water interaction as no chlorine-oxygen-containing ions were found in the solution. The formation of $\mathrm{H}_{2} \mathrm{O}_{2}, \mathrm{OH}^{*}$, $\mathrm{OH}^{-}$in the ozone reaction with aqueous solutions is possible and these reactions are presented in Razumovsky's monograph [5].

$$
\begin{gathered}
\mathrm{O}_{3}+\mathrm{H}_{2} \mathrm{O} \rightarrow \mathrm{O}_{2}+\mathrm{H}_{2} \mathrm{O}_{2} \\
\mathrm{O}_{3} \stackrel{\mathrm{h} v}{\rightarrow} \mathrm{O}_{2}+\mathrm{O} \\
\mathrm{O}+\mathrm{H}_{2} \mathrm{O} \rightarrow 2 \mathrm{OH} \bullet \\
\mathrm{OH} \bullet+\mathrm{O}_{3} \rightarrow \mathrm{HO}_{2} \bullet+\mathrm{O}_{2} \text { etc. }
\end{gathered}
$$

Ivanova and Kontorshchikova [12] observed in the ozonation the $\mathrm{pH}$ shift to the alkaline side from 6.5 to 7.4 in distilled water; from 6.1 to 6.7 in saline solution and by using the chemiluminescence method they showed that in aqueous media, ozone decomposes and generates free radicals. In bidistilled water, the content of free radicals is determined obviously higher than in distilled water and in saline solution. It is caused by available impurities, which quench free-radical reactions. The lifetime of free radicals in distilled water is 2 hours and 40 minutes, and in ozonized saline solution it is 10 minutes. Based on these data, the authors make the conclusion that the therapeutic effect of ozonated solutions is initiated both by ozone and by free radicals. Therefore, they recommended to take ozonated water in the nearest 2 hours and ozonated saline solution within the first 10 minutes.

In their spectral investigations, Zinchenko [13] when ozonizing saline solution, have found a substance with the maximum absorption on the wavelength of $212 \mathrm{~nm}$ having an oxidation ability, the concentration thereof directly depended on the concentration of sodium chloride. To prepare solutions, they used bidistilled water and sodium chloride with the concentration of the latter of $50 \div 150$ $\mathrm{mmol} / \mathrm{l}$. Investigations were carried out at a temperature of $0 \div 23^{\circ} \mathrm{C}$. $200 \mathrm{ml}$ of prepared solutions were bubbled by the ozone-oxygen mixture with the ozone concentration of $30 \mathrm{mg} / \mathrm{l}$ at the gas mixture flow of $2 \mathrm{l} / \mathrm{min}$. The UV spectra of the ozonated solution absorption were recorded by Specord UV VIS, using as a standard sample the same solutions not treated with ozone. During bubbling in the UV spectrum, along with the ozone absorption band with its maximum at $255 \mathrm{~nm}$, an absorption band occurs with its maximum at $212 \mathrm{~nm}$. At the initial bub- bling stage, its intensity increased simultaneously with the intensity of the ozone absorption band, and further the growth slows and in some time, the light absorption intensity reaches at this band a steady-state value. When measuring ozonized solutions with different concentrations of sodium chloride, the authors found that the value of its optical density at a wavelength of $212 \mathrm{~nm}$ after reaching the steady-state value was proportional to the sodium chloride concentration. The intensity of the ozone absorption band herewith continues to grow by reaching in some time a steady-state value. After the dissolved ozone dissimilation, the $212 \mathrm{~nm}$ band continues to be recorded in spectrum. If the bubbling is performed at a lower temperature, the $212 \mathrm{~nm}$ band intensity increases more slowly and the ratio of its strength to the intensity of the dissolved ozone band decreases. Based on this data, the authors make the conclusion that in the course of the sodium chloride solution saturation with ozone, there are formed quite stable chemical compounds of ozone with sodium chloride. The dynamics of such saturation, the ratio of dissolved ozone concentrations, and resulting chemical compounds depend on the time of the solution saturation with ozone and on a temperature.

When analyzing the materials of the foregoing work, it is to be assumed that the observed $212 \mathrm{~nm}$ absorption band is related to ordinary oxygen but not to any new matter. Depending on the measurement conditions and environment in the reaction system, oxygen may appear within the range of 200 to $242 \mathrm{~nm}$ (Herzberg continuum) [14]. Oxygen may also show the absorption within the 240-290 nm range. It should also be noted that in the UV spectrum described by the authors there is no oxygen absorption band and that is an incredible reaction when bubbling the saline solution with the ozone-oxygen mixture.

Kudryavtsev and Galkin [8] carried out the dynamic spectrophotometric determination of by-products formed during the ozonation of distilled water and aqueous sodium chloride solutions $(0.9 \%, 5 \%$, and $10 \%)$. The optical density dynamics was assessed at three band lengths of $220 \mathrm{~nm}, 255 \mathrm{~nm}$, and $295 \mathrm{~nm}$. These bands were selected as the absorption spectra of the most probable substances formed during the $\mathrm{NaCl}$ solution ozonation characteristic for hydrogen peroxide, ozone, and sodium hypochlorite. The data obtained have evidently proved the availability of a substance in the solution, which does not disintegrate after the ozonation and has an absorption spectrum characteristic for hydrogen peroxide. Furthermore, in the $10 \%$ sodium chloride solution, the dynamics of increasing optical density on the $220 \mathrm{~nm}$ length differ wherein, that it has a linear character up to the termination of ozonation. Such dynamics proves the absence of the saturation threshold for such a substance and the better solubility than that of ozone. An increase in the relative absorption at the band lengths of $295 \mathrm{~nm}$ and $220 \mathrm{~nm}$ was identified with an increasing 
concentration of sodium chloride during its ozonation. The absorption dynamics at the band length of $295 \mathrm{~nm}$ is characteristic for hypochlorite and any other chlorine-oxygen compounds. It fully repeats the dynamics at the band of $255 \mathrm{~nm}$. These products are probably formed during the ozonation of sodium chloride solutions but they are unstable intermediate compounds with their concentration fully dependent of the concentration of ozone in solution.

Based on the analysis of the data obtained, the authors make the conclusion that the absorption dynamics at the band length of $220 \mathrm{~nm}$ is characteristic of hydrogen peroxide but different from the ozone absorption dynamics. It is especially noticeable in the ozonation of high $\mathrm{NaCl}$ concentrations and indicates the accumulation and preservation of hydrogen peroxide in the system. Consequently, upon the completion of ozonation after the ozone destruction in the sodium chloride solution, only hydrogen peroxide is identified therein and it should be taken into account in practice when using the ozonated solution of sodium chloride.

The author is declaring that $220 \mathrm{~nm}$ is the absorption band of hydrogen peroxide and is questionable because the latter has a continuous absorption spectrum of 200 to $400 \mathrm{~nm}$. Sodium hypochlorite may not be called an intermediate and unstable product, which allegedly disintegrates and is dependent on the ozone concentration. Apparently, also in this case, the absorption dynamics at $220 \mathrm{~nm}$ depends on the degree of the solution saturation with oxygen. And no products unknown to science were formed in the study conducted by the authors.

Obukhova [15] studied in a comparative aspect the formation of potentially possible byproducts in deionized water and $0.9 \%$ aqueous solution of sodium chloride under different conditions of ozonation. When studying any possible byproducts of the ozone disintegration, the ozone concentration in deionized water was $0.59 \mathrm{mg} / \mathrm{l}$ and $0.67 \mathrm{mg} / \mathrm{l}$; in $0.9 \% \mathrm{NaCl}$ solution it was $0.55 \mathrm{mg} / \mathrm{l}$ and $0.66 \mathrm{mg} / \mathrm{l}$. The hydrogen peroxide content was determined by titration with potassium permanganate in the acid medium and by the colorimetric method using titanyl sulfate. The level of hypochlorite and other chlorine ions was analyzed by titration with methyl orange. The determination of the total nitrite concentration was carried out by the colorimetric method using sulfanilic acid; the total concentration of ammonia and ammonium ions was determined by the colorimetric method using Nessler reagent (GOST 4192-820). The nitrate ion content was investigated by the ion chromatography method (by using liquid ion chromatograph Color-3006). Of all, the known potentially possible byproducts of the ozone self-decomposition only a small amount (about $0.0004 \%$ ) of hydrogen peroxide available in water and saline solution was revealed.

Gorbunov [16] studied the change in the molecular structure of water in the saline solution under the exposure to ozone-oxygen gas mixture. Data submitted by the authors in their paper shows that the larger the multimolecular associations of water molecules (clusters), the worse the quality of aqueous solutions. Large molecular water associations (mega clusters) hardly overcome the intestinal wall. Large clusters felt into the bloodstream also hardly pass the capillary barrier and surely do not get into a cell. In the recent years, scientists have proved that only six-molecular water compositions, the so-called "hexagonal" structures, may easily pass into a cell. By using a high-informative protonography method (the determination of the number and position of hydrogen nuclei) in treating the saline solution (200 ml) for 20 minutes with the ozone-oxygen mixture at the ozone concentration of $20 \mathrm{mg} / \mathrm{l}$, the authors revealed that in this solution, $20 \%$ of small-molecular aquatic structures and the clear majority thereof were such "hexagonal" structures. The authors also showed that before ozonation, the saline solution had been composed of mega clusters, which could not penetrate a cell. The important aspect of the performed study is the fact that having got into the bloodstream, such small-molecular aquatic structures are immediately supplied to those areas of the body where there are any pathological processes (inflammation, ischemic zones etc.). This occurs because the aqueous media of the body are a powerful informative field, which controls all processes. According to Demlov, Jungmann [17], cells in a pathological focus area are in the state of excitement and it becomes known to the common water information field, which is supposed by some scientists to be the most powerful "biological computer". This "computer" sends to a suffering damaged cell such small-molecular "hexagonal" water structures, which recover its activity. Ozone therapists have noted that ozonated crystalloid solutions (disol, trisol, Ringer's solution, cardioplegic solution) have a more pronounced therapeutic effect than non-ozonated ones [18-22]. There has been no explanation of this fact. Considering the data that electrolytes penetrate into the intercellular and cellular space only when surrounded by water molecules (hydro-envelope), it is reasonable to assume that with ozonation of crystalloid solutions such "hexagonal" water structures are formed, which serve as the main transporting facility for ionized electrolytes to aqueous sectors of the patient's body.

The formation of the small-molecular aquatic structures when treating the saline solution with ozone-oxygen gas mixture is confirmed by the crystalloscopic study of ozonated solutions conducted by Boyarinov [23]. The authors bubbled in $500 \mathrm{ml}$ container the saline solution with the ozone-oxygen gas mixture at the ozone concentration of $5,10,40$, and $60 \mathrm{mg} / \mathrm{l}$ at the outlet of the ozone generator (Medozon, Russia) for 10, 15, 30, 45, and 60 minutes. In control time points they took ozonated solution and measured the content of dissolved ozone therein with the aid of the same device. At the same time, 
they applied to a clean degreased glass $100 \mu$ l of ozonated solution related to each series of experiments as well as saline solution before ozonation (intact specimen).

The dehydration of saline droplets was performed in laboratory conditions without additional thermal stimulation. The viewing and photographing of facies (crystallizate-samples) were carried out with the aid of measuring microscope Hawk (the United Kingdom) and automated microhardness tester VMHT AUTO MOT (Germany). The analysis of crystallograms was performed based on the morphology of formed facies and visual-metrically by using a criteria assessment system [24]. As the main valuation parameters, they used a tezigraphic index, which reflects the direction and intensity of the initiating effect of ozonation; crystallinity characterizing the complexity of the facies structural elements; the degree of the facies destruction indicating the "correctness" of the structure building and the intensity of the marginal zone of microslide. Based on the analysis of crystallograms, the authors have determined that peculiarities of the crystalloscopic pattern conversion directly depend on the current ozone concentration and the treatment time. Thus, in the short-term bubbling mode (15 minutes), the stimulation of the saline structuring was observed and the intensity of this effect was inversely proportional to the current ozone concentration: while bubbling $10 \mathrm{mg} / \mathrm{l}$, the whole facies was provided with numerous tightly packed fine crystal elements, while with the use of the high concentration $(60 \mathrm{mg} / \mathrm{l})$ there were detected on a microslide some islands' formed by numerous small crystals. This is confirmed by data of a visual-metric analysis indicating the marked elevation of the tezigraphic index and crystallinity in treatment of saline solution with $60 \mathrm{mg} / \mathrm{l}$ of ozone $(p<0.05$ for the both parameters). On the contrary, when using a lower concentration of the agent $(10 \mathrm{mg} / \mathrm{l})$, only a small increase in the tezigraphic index was noted as compared to an "intact" specimen $(p<0.05)$.

The dependence of the saline crystallization nature on the time was nonlinear. Thus, the most short-term treatment thereof with ozone (for 10 minutes) as well as the 15-minute bubbling have provided a moderate increase in the crystallogenic potential of liquid under study favoring small but statistically significant increase in tezigraphic index (up to 3.75 and $3.5 \mathrm{CU}$, respectively; $p<0.05$ for the both cases) and crystallinity (up to 1.5 and 1.25 points, respectively; $p<0.05$ for the 10-minute treatment with ozone). The further extension of the treatment time (up to 30,45 , or 60 minutes) caused inverse shifts providing for the crystallization inhibition slightly dependent on the period of bubbling (the level of tezigraphic index was within 2-2.5 CU; $p<0.05$ as compared to an "intact" specimen of saline solution). It was associated with the decrease in the crystallinity value reaching its maximum ( 0.5 points) at the most prolonged treatment (60 minutes). It should also be noted that with the increasing duration of the bubbling period, a significant decrease in the formation of the marginal zone of a microslide occurs. Thus, the treatment of the saline solution with gaseous ozone significantly transforms the result of its crystallization and the intensity and direction of this modulation effect nonlinearly depend on the ozone dose and the duration of the treatment.

\section{CONCLUSIONS}

The analysis of the published data on the ozone and $\mathrm{NaCl}$ interaction in aqueous solutions enables us to make the conclusion that during the treatment of these solutions with the ozone-oxygen gas mixture (in exposures, concentrations of ozone and $\mathrm{NaCl}$ as stated in papers) and the subsequent ozone decomposition therein, ozone does not interact neither with $\mathrm{Na}^{+}$nor with $\mathrm{Cl}^{-}$; neither sodium hypochlorite nor any other chlorine-containing oxygen ions, nitrates and nitrites are formed. There are identified dissolved oxygen and ozone, and in the reaction of the latter with water there are produced free radicals, hydrogen peroxide (in a small amount), and hexagonal and small-molecular aqueous structures. Hexagonal aqueous molecules formed during the ozonation of aqueous solutions improve the transport across the cell membrane not only of electrolytes but probably of any other substances. Thus, Boyarinov and Sokolov [25] have shown that when performing the ozonated bypass, more glucose is utilized by cells of the patient's body than during the oxygenated bypass. Thus, dissolved ozone, free radicals, hydrogen peroxide, and hexagonal aqueous structures resulting from the bubbling of aqueous $\mathrm{NaCl}$ solutions with the ozone-oxygen mixture produce a therapeutic effect of the ozonated saline solution.

\section{DISCLOSURE}

Authors report no conflict of interest.

\section{References}

1. Bocci V. Ozone as a bioregulator. Pharmacology and toxicology of ozone therapy today. J Biolog Regulators and Homeostatic Agents 1997; 10: 31-53.

2. Густов АВ, Конторщикова КН. Потехина ЮП. Озонотерапия в неврологии. Н. Новгород: Из-во НижГМА, 2012; 192 с.

3. Зайцев ВЯ, Разумовский СД. Озонидотерапия//В кн.: Озон и методы эфферентной терапии в медицине: Тез. докл. III Всерос. научно-практ. конфер. Нижний Новгород 1998; С. 11-12.

4. Бояринов ГА, Перетягин СП, Монахов АН, Горбунов СН, Гордецов АС, Соколов ВВ. Исторические аспекты интрасосудистого пути введения насыщенных озоном растворов. Результаты, нерешенные задачи и перспектива развития данного метода//В кн: Озон и методы эфферентной терапии в медицине: Тез. докл. III Всерос. научно-практ. конфер. Нижний Новгород 1998; С. 136-142. 
5. Разумовский СД. Физико - химия озона и ее биохимические и медицинские приложения//В кн.: Озон в биологии и медицине: Тез. докл. II Всерос. научно-практ. конфер. с международным участием. Нижний Новгород 1995; С. 4.

6. Бояринов ГА, Гордецов АС, Бояринова ЛВ, Шамелашвили ИН, Кулагина НВ, Зимина СВ, Соколов ВВ, Калягина СГ. Результаты анализа потенциально возможных реакций озона с хлоридом натрия в воде//В кн.: Озон и методы эфферентной терапии в медицине: Тез. докл. III Всерос. научно-практ. конфер. Нижний Новгород 1998; С. 6-9.

7. Зайцев ВЯ, Константинова МЛ, Подмастерьев ВВ, Разумовский СД. К врпросу озонирования физиологических растворов для медицинских целей//В кн.: Озон и методы эфферентной терапии в медицине: Тез. докл. III Всерос. научно-практ. конфер. Нижний Новгород 1998; С. 3-4.

8. Кудрявцев ВА, Галкин АА. Динамическое спектрофотометрическое исследование процессов, происходящих при озонировании воды и растворов хлорида натрия// Казанский мед. журнал. Приложение 2007; 88: С. 301-303.

9. Puckrius PR, Hess RT. Ozon use in cooliny water systems case history of a monitored usage and guidelines for potential application//Ozone in water and wastewater treatmen. Proc Eleventh Ozone World Congress, San Francisco, CA, USA, 1993; 2: S-11-1-S11-22.

10. Федоровский НМ. Проблема эндотоксемии и методов ее коррекции (Обзор по материалам Х Всероссийского Пленума анест.-реан.)//Вестник интенсивной терапии 1995; 3 : C. 53-54.

11. Кудрявцев ВА, Большухин СЮ. К вопросу озонирования растворов хлорида натрия// Нижегородский мед. Журнал. Приложение к НМЖ «Озонотерапия» 2005; С. 44-45.

12. Иванова ИП, Конторщикова КН. Физико-химические свойства озонированных растворов//В кн.: Озон в биологии и медицине: Тез. докл. II Всерос. научно-практ. конфер. с международным участием. Нижний Новгород 1995; C.10-11.

13. Зинченко ВД, Мусина ИА, Голотова ВИ, Таран ГВ. О динамике насыщения озоном водных растворов хлористого натрия//Нижегородский мед. журнал. Приложение к НМЖ «Озонотерапия» 2005; С. 41-42.

14. Пыряева АП. Изучение механизма фотогенерации синглетного кислорода из столкновительных комплексов X O 2 (X= O2, N2, C5H8). Автореф. дис. канд. физмат.наук. Новосибирск 2014; 22 с.

15. Обухова ЛМ, Конторщикова КН, Мухина ИВ, Евдокимова ОС. Сибиркин АА, Гусовский ДИ, Чернова ОЮ. Разложение озона в водных растворах: кинетика и побочные продукты//Revista Ozonoterapia 2009; 3 Suppl.: 49-51.

16. Горбунов СН, Корноухов АЕ, Можаев МВ, Фролов МВ, Афанасьева АВ, Докунин АА, Горбунова ЛВ. Структурно-молекулярные трансформации водных растворов электролитов под воздействием медицинского озона// Медицинский альманах 2013; 27: 38-40.

17. Демлов Д, Юнгман М-Т. Руководство по кислородной и озонотерапии. Практика - клиника - научные основы. Пер. с нем. Москва: Арнебия 2005; 208 с.
18. Бояринов ГА, Монахов АН, Медведев АП, Чигинев ВА, Бобер ВМ, Гамзаев АБ. Влияние озонированного кардиоплегического раствора на кардиогемодинамику при протезировании клапанов сердца//В кн.: Озон в биологии и медицине: Тез. докл. II Всерос. научно-практ. конфер. с международным участием. Нижний Новгород 1995; С.39.

19. Бояринов ГА, Никольский ВО, Монахов АН, Смирнов ВП. Влияние озонированного кардиоплегического раствора Деринга на функциональный элемент миокарда// Информационный сборник «Реаниматология и интенсивная терапия. Анестезиология» 2000; 4: С.19-20.

20. Костяев АнА, Костяев АлА, Циркин ВИ, Конопельцев И. Влияние озонированного раствора Кребса на автоматию и $\beta$-адренореактивность изолированного миометрия крыс// Информационный сборник «Реаниматология и интенсивная терапия. Анестезиология» 2000; 4: С.25-26.

21. Лаберко ЛА, Родоман ГВ, Оболенский ВН, Коротаев АЛ, Никитин ВГ. Свойства и способы повышения эффективности озонированных растворов в клинической практике// Информационный сборник «Реаниматология и интенсивная терапия. Анестезиология» 2000; 4: С.9-10.

22. Семенов БВ, Фирсов ОВ, Еремин ЕИ. Озонированные растворы кристаллоидов в лечении острого пиелонефрита, осложненного уросепсисом//В кн.: Озон в биологии и медицине: Тез. докл. II Всерос. научно-практ. конфер. с международным участием. Нижний Новгород 1995; С.50.

23. Бояринов ГА, Мартусевич АК, Матусяк КС, Овчинников ЮВ, Горбунов СН. Результаты анализа кристаллограмм озонированного физиологического раствора//Биорадикалы и антиоксиданты 2016; 3: 77-81.

24. Мартусевич АК, Гришина АА. Биокристалломика: общие представления, методология и методы исследования// Учебное пособие. Киров 2009; 26с.

25. Бояринов ГА, Соколов ВВ. Озонированное искусственное кровообращение (экспериментальное обоснование и результаты клинического применения). Изд-во «Покровка». Нижний Новгород 1999; 318 с.

\section{AUTHORS' CONTRIBUTIONS}

GAB, ASG, SPP prepared research concept of the publication. ASG and LVB collected data. LVB analysed data. GAB wrote the article. SPP critically reviewed the publication. AKM finally approved it. 